\title{
Participating in the Global Competition: \\ Denaturalizing "Flair" in Samoan Rugby
}

Julien Clément

\section{"Flair" from France, “Flair” from Pacific Islands: A Critique}

The question of "flair" resonates in a very different manner in France, New Zealand, or Sāmoa. "French flair" is an expression used by commentators to nickname the supposed collective inspiration that the French national team is sometimes capable of. It has been analyzed as a distinctive style of play. ${ }^{1}$ But the "magical" aspect of the expression has been explained by scientists of physical and sporting activities in terms of the practices of and approaches to the game (see Bouthier 2007). Its genealogy can be traced in coaching methods such as those defined by René Deleplace, whose 1979 book crystallized a distinctive training style and approach to the game that was subsequently characterized as "French flair."

The term "flair" involves two different and opposite aspects: On the one hand, it is used to describe a distinctive style of play, which in turn refers to a tradition of conceiving and coaching the game that has been transmitted and has evolved through a social history of sports institutions, theories, and contacts. But on the other hand, people who evoke this term generally seem to be oblivious to these practical formations of this distinctive style of play.

When I left France for Sāmoa, my purpose was to study a different practice of rugby. In particular I wanted to study the sociocultural formation of body techniques, following a Maussian line of research (Mauss 1979). Being from a French background, I wanted to compare the rugby I was used to with the rugby played in the South Pacific. However, at that time I did not know that Pacific Islands' styles were also characterized as having "flair."

The Contemporary Pacific, Volume 26, Number 2, 369-387

(C) 2014 by University of Hawai' $i$ Press 
Once my research was underway, I came to realize that the Samoan style was characterized by both "flair" and "aggression." My research on the social formation of techniques of the body led me to critique these terms. I denaturalize "flair" in Samoan rugby by pointing to the social conditions in which body techniques are formed and the position of the actors who comment on rugby in Sāmoa.

However, there is much more to this question of "flair" than my own position. The influential proximity of New Zealand, where rugby is the national sport, determines a totally different meaning of "flair" than that implied by the phrase "French flair." The characterization of "flair" for Pacific Islanders must be understood in the context of discourses about Polynesian and Maori masculinity. ${ }^{2}$ Relying on the stereotype attached to Māori and Pacific Islanders as "physical beings" (Hokowhitu 2003) since the colonial era, these naturalizing discourses reaffirm Islanders' innate difference from white settlers and confirm their status as "outsiders" (Grainger 2009; Grainger and others 20I 2).

My research in Sāmoa confirms the existence of differences in terms of bodily techniques and game play. It is complementary to analyses of "flair" because it denaturalizes "flair" by showing the social conditions under which these body techniques exist and endure.

\section{Rugby in SĀmoa and the InTERnAtional Competition IN RugbY}

On the 6th of October I99I, Western Sāmoa's national rugby union team defeated the Welsh team in the second Rugby World Cup in Cardiff. This was the first time the World Cup had been organized in the British Isles and the first time a Samoan team had participated. The Samoans defeated one of the best national teams in the history of the sport in its home stadium, the famous Cardiff Arms Park. One Welsh commentator commemorated this defeat with a joke: "At least it was only Western Samoa!" (referring to the division of the Samoan archipelago into two different political entities, American Sāmoa and Western Sāmoa). Since then, the Samoan team has maintained its prowess and its presence in subsequent Rugby World Cups.

Before each game, the Samoan players perform a specific dance called "Siva Tau." Siva Tau literally means "dance fight." This performance identifies them as Polynesian men and plays on the warrior image attached to them (Uperesa 20I0; Tengan and Markham 2009; Hokowhitu 2003, 2004). Their style is impressive and in some ways reinforces this image: 
players tackle with great force. But they also feint and sidestep with impressive agility and lightness of foot in one-on-one situations.

These qualities attract attention to the Samoans at a global level. When the Samoa Rugby Union (SRU) was signing a contract with Puma to sponsor the national team in 2005 , the official press release by the global sports brand described the team with the following words: "In the game, Manu Samoa has firmly emerged on the professional rugby scene as a strong competitor with a combination of fast paced, powerful, dynamic play and flair."3

Within the Pacific, the Samoan team participates in international competition alongside Fiji and Tonga (Besnier 20II, 20I2; Dewey 2006, 2008). Since the definition of the rules in London in I863 (Holt I989; Eisenberg and others 2004), the Rugby Union has enjoyed a long history in the Pacific, with the first game played in 1870 in Nelson, New Zealand (Ryan I993, 2005a, 2005b). Rugby Union was promoted in New Zealand by former British public school boys. Under British and New Zealand influence, rugby was introduced throughout the Islands and is now a major pastime in Fiji, Tonga, and Sāmoa. Since the inauguration of this competition in 1987 , these three teams have always taken the three spots reserved for Oceania in the World Cup.

Sport is one of the few areas in which these countries "on the edge of the global" (Besnier 20II) can compete at an international level. As analyzed in various articles in this special issue, this opportunity for the countries to assert themselves is doubly important: first, sport is one venue for development of Pacific nations, with all the ambiguities of such a program (see Kwauk and Mountjoy, both this issue); second, it may open various opportunities for Pacific people, even though they may become illusory possibilities (Uperesa, this issue). Along with gridiron football in American Sāmoa and, to a lesser extent, Hawaíi (Uperesa 20Io; Tengan and Markham 2009), rugby is one of the few sports in which Pacific Island countries achieve international success.

However, the creation of a Rugby World Cup in 1987 has changed the rules of the game; rubgy and its economy have been radically transformed since then. As Brett Hutchins and Murray Phillips noted: "Over the last three decades rugby has been transformed from an inwardly-focused game played at local, provincial and national levels ... to a quadrennial, globalized, sporting spectacle played by professional athletes from a growing number of nations" (1999, I 58 ).

The Rugby World Cup tournament was created by the International 
Rugby Board (IRB), the international nongovernmental organization that both defines the laws of the game and organizes the main international competitions. It is now the third most watched global sporting event in terms of television audiences, after the Soccer World Cup and the Olympic Games. This evolution places rugby in the new economy, analyzed by Kimberley Schimmel, in which "transnational corporations [medias and sponsors] and international non-governmental organizations that control international sport [the IRB, in this case] form new alliances in the domain of sport" $(2005,3)$. This evolution has caused rugby to be redefined along new lines.

Sāmoa, as well as other Pacific Island countries, including places where rugby has recently arrived, was a major part of the global outreach plan developed by the IRB since I995. The participation of the Manu Samoa in the Rugby World Cup tournaments invites us to interrogate the link between Samoan society and the actors of global sport in order to gain a better understanding of the contemporary form that rugby in Sāmoa takes.

In this article I present the social context in which rugby is practiced in Sāmoa in the broader perspective both of the development of rugby internationally and the discourse on "Pacific flair." I analyze the specific configuration of rugby in Sāmoa based on fieldwork I conducted in 200I, 2005 , and 2006 in various clubs and schools in the Apia area. Their distinctive style of rugby play does not imply ill-conceived Pacific attributes but points to very real tensions and social dynamics that are taking place at the village, national, and global levels.

\section{Double Inscription: Rugby and Village}

\section{The Samoan Rugby System}

The first Apia Rugby Union was founded in 1927. It was a provincial union, affiliated with the New Zealand Rugby Union. At the time, New Zealand had a mandate from the League of Nations to exert a colonizing power on Western Sāmoa. ${ }^{4}$ Rugby had become the national pastime in New Zealand, in part after the successful tour of the national team in the British Isles and France in 1924-the team was nicknamed "The Invincibles" because they won every game (Belich 200I). This shared history led to the Samoan rugby system following the New Zealand model.

From 1927 till the present day, varying levels of competition, from provincial unions to international ones, are nested within each other. At the 
local level, games take place between clubs and are organized by provincial unions, who then select players to compete in the national championship between provinces. At the top of this system stand the Manu Samoa, under the direction of the Samoa Rugby Union, the nation's premiere rugby institution.

As in 1927 , the vast majority of the clubs today are based in villages. The latter are the most important social units in Sāmoa. These villages are constituted by a network of extended families residing on the same land from generation to generation through customary tenure. ${ }^{5}$ Titled chiefs are the heads of the families with authority emanating from various sources recognized in customary formal expressions or salutations called fa'alupega (the latter are repeated in any formal situation in which chiefs are involved). Their inherited titles might trace back to the founding of the village, to a historical event in the archipelago, or to a moment when an ancestor demonstrated exceptional prowess on behalf of the village, for example. Titled chiefs are part of the fono, the chiefs' council that rules local life in the village, with authority guaranteed by the Samoan Constitution. As a consequence, like all village activities, rugby clubs are under the chiefs' authority, and the club can be forbidden to participate in any competition if the fono is unhappy with the behavior of the club (in case of repeated involvement in violence, for instance).

The young untitled men of the village are called taulele'a (non-titled men; singular: taule'ale'a), gathered in a group called the 'aumāga. In the past, the tattooing of young men was the principal rite of passage for entering the 'aumāga (Galliot 2010). Now, when they finish schooling, young men or their families ask the leaders of the 'aumāga for permission to join it. As members of the 'aumāga, both in their family and in the village, the untitled men have specific duties, under the command of the chiefs. Most of their responsibilities are linked to their strength: they take care of the plantations, help with constructing and repairing buildings, carry objects or food when necessary, and enforce the chiefs' decisions if someone does not respect them. The ceremonial name of this group is "o le mālosi o le nu'u" (the force of the village).

The sport and village systems are mixed in rugby, and the various institutions, to a different degree, are integrated in both organizations. A club belongs to the official sport structure linked to a provincial union, which is itself affiliated with the national union, while chiefs are represented in the administration of the clubs and unions. Families donate money for the teams, players gather to play every evening and participate in the competi- 
tions on the weekends, and the teams use common spaces of the village or the private homes of club members to hold practices and meetings. Games are held in fields available in the province under the authority of sports administrators, who are most likely among the region's main chiefs. Every institution has this double aspect of being part of the two social organizations at the same time.

Among all the clubs, there are also differences. The clubs from the villages near the capital, Apia, are the best in the country and the closest to the international scene. They are the oldest clubs, since rugby started in the capital, and they attract players from various other provinces who want to get selected for their respective provincial teams. Indeed, with internal migration for school and for jobs, many young men move to villages near Apia specifically for rugby opportunities. As they join the best clubs in Apia, they become part of the gathering of young men on rugby fields. The two aspects-Samoan social organization and rugby as an institution-are always present to some degree, even in the clubs closer to the international organization of rugby.

\section{The International Rugby Board's New Economy and Development Policy}

The rapidly growing financial stakes within rugby after its professionalization in 1995 led to Samoan rugby's most influential figures asking the International Rugby Board for more economic support at all levels in order to meet the needs of international competition. As an example, training equipment such as scrum machines, tackle bags, protective gear, balls, and especially gym facilities were generally lacking. In this respect, I expected the relationship between the IRB and Samoan rugby to be one of support for the already existing structure. However, the IRB development policy consisted not only of providing Samoans with money and rugby equipment but also of building a national administrative and coaching infrastructure according to the New Zealand standards, since New Zealand was considered to have the best rugby organization in the Pacific area, if not the world, and was already the model after which the Samoan sports institutions were built.

Starting in I995, representatives of the IRB established offices for the Samoa Rugby Union according to corporate standards with computers, faxes, and so on. In a second phase, beginning in 200I-2002, international coaching methods based on the New Zealand curriculum were implemented by conducting seminars and clinics. Diplomas were deliv- 
ered, eventually requiring travel to New Zealand for specific sessions. In a third phase, initiated in 2005 , new regional competitions were implemented at a Pacific level. A "High Performance Unit" for elite players was also created. Both initiatives in the third phase helped develop a path to international success for Samoan-based players. Following the logic of development through sports, and rugby especially, the Samoan government and the IRB worked hand in hand to promote the Samoa Rugby Union as the main provider of resources for rugby players and institutions in Sāmoa.

While the formal structures of rugby were undergoing these changes, Samoan village practices, described in the next section, continued to take a distinctive form.

\section{Games in the Villages}

In contrast to the situation in my native suburb of Paris, where access to a rugby pitch is contingent on registration in a club, Samoans of various ages can be seen playing informal games on the front lawn of their houses, on school playgrounds, in communal village spaces, on the beach, or even in the lagoon itself. Such games are typically "touch" rugby, wherein tackling is replaced with a simple touch on an opponent's body. A great many sports matches, including rugby, occur at the end of the workday and before sunset-from 5 PM to 7 PM-and attract most young men in the area.

At the end of each working day, I would go to the rugby field five minutes away from my home with the three male members of my Samoan family: a thirty-four-year-old high school teacher, a fifteen-year-old student at the same high school, and a young man of thirty who was fulfilling his duties of taule'ale'a in the house. We would meet the other men willing to play "touch" rugby in the area and play for an hour or two before going back home for the evening prayer and dinner. The games elapsed with much joking and talking among the participants. Moreover, during this time, men were also learning crucial skills such as sidestepping, feints, quick passes, and others apparent in later official competitions. ${ }^{6}$ Playing fields are important places to develop proficiency in rugby and specific techniques of the body.

Even though their importance to Samoan rugby is obvious, the games still seemed to be a random leisure activity. The connections to Samoan social organization, on the one hand, and to sports institutions, on the other hand, were difficult to grasp. They were not readily apparent at first, 
but experiences in the villages illustrated them and helped me to understand the broader picture of Samoan society and Samoan rugby.

Oddly enough, the funeral of a village pastor was instructive. While I cannot go into all the details of the activities described here, what struck me was the place of the rugby games during that time. A game was played every evening, except during the actual ceremony, although there are no prohibitions against playing during ceremonial preparations. However, for me as an ethnographer, it was a chance to see rugby taking place within the frame of intensely communal life. Rugby became a place for young men to relax after a day of work and difficult responsibilities, where they could freely play and laugh together. While previously I had been focusing on the organization of rugby I was used to, that is, the formal practices within the framework of a sports institution, this experience in the village at this specific time helped me to understand the link between rugby and the villages as social units.

Rugby plays an important role in young men's socialization as they represent their families and villages in competition for local audiences composed of the chiefs, kin, and young women for whom the players want to build their personal and communal reputations. A few days before an important game, members of the teams gather in a camp. On completing their daily tasks, they practice and rest together. As at international levels of competition, camps allow players to assemble for the purpose of focusing on the game. However, as inscribed in the village, playing rugby also manifests the existence of the untitled men's group and the belonging of the club to the village. In the past, young men were initiated into the 'aumāga through a ceremony in which young men were gathered and separated from the rest of the village. This is no longer practiced; nonetheless, the professional practice of camp is reformed on new ground, in which the specific Samoan social unit of the village imparts the camp unique form and meaning. Rugby is not part of the duties of the 'aumāga, but most of the members of the latter like to play rugby and want to be part of the team that represents the village in the competitions. Rugby takes place in the context of and is surrounded and influenced by fa'asāmoa (the Samoan way of being and doing things).

\section{Samoan Rugby Techniques}

If in each country each coach chooses his own way of practice, there are still some national differences based on conceptions of the game that are widespread and are the basis for the formation of coaches by federal 
unions (for a detailed analysis of this question for rugby coaching in New Zealand and France, see Bouthier 2007; Clément 2009, 2010). When I was learning rugby in France at the age of thirteen, touch rugby was the common form of training that my coaches chose for us to practice. In the approach to the game defined by the Fédération Française de Rugby (French Rugby Union) and in its curriculum for coaches, ${ }^{7}$ learning rugby skills requires that a large portion of practice takes place in "opposition situations" - two teams must play against one another from opposite ends of the field-closely reproducing the actual game.

On the other hand, in the New Zealand Rugby Union curriculum for coaching diplomas, ${ }^{8}$ the practice of skills often occurs without any "opposition situations." Practices are divided between skills, fitness, and game plans, so that the players become very efficient in putting pressure on the opposition by executing game plans prepared in advance.

In the games I observed in Sāmoa, the approach is different again. Informal games are generally based on individual oppositions. Players attempt to relax in spite of the friendly competition with ongoing jokes throughout the game. One-on-one situations are created with feints or sidesteps being used to beat the opponent and tease the other player or to make everybody laugh. Races to outpace an opponent follow these interactions and are also very spectacular and exciting for players. Through rugby, reputations and rivalries can be worked on during the informal games, which are part of the socialization of young men in their villages.

In a similar manner, the rugby team holds the name and the honor of the village when entering the field. Success in the competitions is considered a way to serve the community. Young untitled men have to show that they are mālosi (strong), individually and collectively. The main actions in this respect are hard tackles, which are enthusiastically cheered by the audience. The body technique that identifies Polynesian players is tackling the upper body. The aim is to dislodge the ball from the carrier, as well as to clash with him to make the tackle more spectacular for the spectators. This double approach of opposing individual interactions is linked to the internal dynamics of the village and to masculine embodiment (Clément 20I0).

\section{Perception of Informal Games by IRB Representatives}

Despite the fact that body techniques are being developed in these informal games in the villages, they are often considered to be mere social games by IRB representatives. I attended a two-day IRB workshop for schoolteach- 
ers who coached school teams. No mention of these games was made. Similarly, I noticed their absence in documents and discussions I had with most of the rugby officials. At the end of my fieldwork, I had the chance to interview the IRB regional development manager (RDM) for Oceania in order to confirm I was not overestimating this dimension:

JC: And what about, I mean, even the adults are playing touch rugby every evening.

RDM: Yeah. It is for recreation.

JC: ... You have nothing to take from that, in terms of development of rugby? RDM: Because ... well, it has no future. It is an end in itself. It is the pick of the men from the village, get out, they put some coconut shells to mark up the field, and they are just having a game of touch rugby! Lots of laughs, lots of forward passes, just let it go! You know....

JC: But so you think ... it is for you ... it's not something that is helping development of rugby in a sense?

RDM: ... I am not, quite honestly, I am not familiar enough with it, to know what really does happen.

JC: You didn't have a look properly?

RDM: No. No. It's always been the structured stuff, given the limited amount of time we are there. But we...

JC: What do you mean?

RDM: Well, we are not there enough to worry about that side of it. That's almost social rugby, and we've got to be a little bit more deliberate than that.

This exchange emphasizes the way the IRB's main representative, who was often on the field to help coaches in Sāmoa, considers informal games in the villages: as something social, not "structured." Overlooking these games creates a blindness to the formation of specific body techniques. These techniques are then observed in the games as a difference, but they are described as "flair," and a long history of colonial discourse frames this vision. Skills like feints or sidesteps in one-onone situations, quickness and control in passes, as well as tackling with speed, trying to destabilize an opponent in his control of his body and the ball, are not understood to be the product of the social environment of these teams. 


\section{A Samoan Rugby Game}

\section{Competitions and Relations between Villages}

The Samoan competition is modeled after the classic version of British competitions, with various team clubs competing every week in a championship. At the same time, the internal rivalries inscribed in Samoan social organization and histories are at play during the games, as described by a former coach of one of the most prominent teams:

JC: What do the people of the village think about the rugby team?

СОАСH: Oh, actually you will see tomorrow. Usually B and C are one in the custom, but when they play rugby [against each other] ... everyone looks at it as the game of the year.

JC: Oh, really?

СОАсH: Yes. They are two rival clubs, but they come from one, just like one family. B, C, and D, they are one family, but when they play rugby ... the other one doesn't want to lose. It's the pride! It's the pride that they are playing for ... because if we lose today, you'll be hurt for quite a while. Because there is too much pride between these clubs. . . Because B, C, and D, we have one customary fa'alupega.... That's the sort of pride that we people take in our rugby and how we protect the reputation of the club and the village!

Village relationships are central to the competition, even more than the actual vehicle of competition itself. The pride and name of the respective villages justify such intense rivalry, so that their logic is surrounding the competition at every stage. This type of relation is constantly at play between the villages due to various histories, genealogies, and customary rivalries.

Yet these rugby games are also part of competitions in which selectors and other amateurs observe how players perform in a way that is more familiar to the West. After the week's preparations, on game day the players follow a classic team warm-up. They eat together, come up to the field, and watch parts of the other games. As game time approaches, they warm up next to the field with physical exercises and repetitions of the main patterns for different phases of the game (line-outs, scrums, etc). Just before the game, the players pray together. If the players attend different churches, it does not influence this collective moment: all members of the team gather in a circle (each with an arm stretched toward the center), 
close their eyes, and hang their heads; all bodies touch each other; a player says a prayer with a soft voice, and then they all go to play.

\section{Supporting the Village Team}

The village's supporters watch from the main stands, seated on either side according to their allegiance. Some families or specific supporters go to another smaller stand on the opposite side of the field. Families, friends, and fans surround the team. When it takes the field, the team appears again in a double inscription, both as a sports club and as an emanation of the village.

During the game, the fans cheer for their team but rarely sing or clap as a collective. Instead, they may shout individually or express their joy after an exciting play, especially a hard tackle. In contrast, in school level rugby, students gather to follow the orders of a leader-a fellow student. This form of heated "fandom" exists in Sāmoa, but for the village level, the support takes a different form.

In fact, a more subtle exchange takes place; when players are congratulated after a game, they reply, "Mālō le tāpua'i!" This expression is common in Sāmoa when someone does something: When a bus driver is thanked, "Mālō le tāpua'i!" (Congratulations, and thanks for the drive), he or she responds with the same words, "Mālō le tāpua'i!" (Congratulations, and thanks for your silent prayer!). The word "mālō" means "congratulations" or "well done" and is an exclamation of acknowledgment as well as encouragement given to someone performing a task (Milner I976). It also refers to "victory," "winner," and "government." It is used in these interactions to indicate submission to an interlocutor and is a sign of politeness. With the word "le" followed by the verb describing the designated action, it indicates both congratulations to honor the person and gratitude if the interlocutor benefited from the action. "Tāpua' $i$," on the other hand, is the verb "to pray" in today's language. In ancient Sāmoa, it referred to an ancient practice called tāpua'iga (an act of worship in today's language) that involved silent prayer or meditation during a potentially dangerous action such as going to war, fishing in high seas, or traveling great distances. In the past, those who remained in the village would gather in a circle within a fale (house) with drawn pola (blinds) and place themselves under taboos (the word comes out of tāpu, root of the word tāpua'i) to be in communication with deities through silent prayer. These rituals seem to have disappeared, and if the expression remains, it is difficult to know its significance for Samoans today (for these ele- 
ments, see Tcherkézoff 2003, I89-190). When I asked people, they simply answered either that it is an expression of politeness or that it is a way to express their sincere thoughts for someone. Elinor Ochs defined the nature of these linguistic exchanges in the following way: "Whether building a house, singing a song, fixing a broken tool, driving a car, Samoans know that they can usually count on the company of one or more sympathizers. The relationship between the actor and the supporter is truly reciprocal rather than unidirectional" (I988, I99).

The support is not just help given to the person who physically undertakes the action but more of a collaboration in an action considered as collective: "The tāpua'i facilitates the accomplishment of the task through supportive remarks and encouragement directed toward one or more persons who are engaged in or who have just completed some physical activity. Both the tāpua' $i$ and the one(s) performing the more active aspects of the task are seen as carrying out the task" (Ochs I988, 78).

In Ochs's research about socialization of children to languages (marked in Sāmoa by the necessary learning of a social order), this context contrasts with the classroom where pupils' individual accomplishments are underlined by the teacher, whose own role remains outside the action of learning. In this case, instead of "mālō," the word "lelei" (good) is used.

In reference to a rugby game, the expression "tāpua' $i$ " means something important, as argued by Serge Tcherkézoff:

In the stadium, the spectators are the side tāpua' $i$, players are the other side, the side of action; and here too, it is clearly stated that it is not the second side that makes the result, because "it is not superior to the tāpua'i." It is the tāpua' $i$ that is the matrix of the action or, at least, its result. Spectators are much more than "supporters" of a sporting club. Without them, there would not be any game or any results. They say they are here to tāpua'i... This hierarchical opposition tāpua $\mathrm{i} / \mathrm{action}$ (here: spectators of the village/players of the village team, those who do the tāpua' $i /$ those who make the action) is always the very strong manifestation of a social group.... So it is always really two whole villages that are present in a stadium. $(2003,193)^{9}$

In this respect, I agree with Tcherkézoff's interpretation of tāpua'i in the stadium. The religious overtones and the way this silent prayer works is still open for analysis, but as a collective that is present on and brings its force to the field while defending a village name and all the chiefly titles and fa'alupega attached to them, the expression of tāpua'i must be understood as an important dimension of Samoan rugby games. 


\section{Exchanges}

At the end of a game, players from both teams assemble in front of the chiefs of the two villages-most often sequentially, but sometimes collectively - and say a few words of respect to honor them. In response, the chiefs make short speeches to express their gratitude and add words of wisdom and encouragement for the future. On one occasion, the manager of the winning team gave to the losing team a portion of the prize money offered by a sponsor. In these ritual exchanges, the two social groups reestablish peaceful relations after a moment of (sporting) confrontation (Mauss I990).

Sponsorship and product promotion in Samoan rugby matches, as well as the sport's British institutional structure, are similar to most rugby environments in the West. However, crucial rivalries are embedded in the long history of inter-village relations. In this encounter, the various actors create a Samoan game of rugby. It is not a new form of rugby as in kilikiti, a version of cricket in which bats, rules, number of players, and so on are different from the original game. Nor is it just a reiteration of the original game. It is the same form, but with Samoan elements inscribed within the game itself.

\section{Conclusion}

Sport has become an important means of developing individual, community, and state identities in the Pacific. It is also an important area for international nongovernmental sporting organizations that control the various games. As they develop the sport globally, the Pacific countries seem to be a potential space for furthering the competition and diversifying it with new cultures, new images, and new players.

The study of the local arena of development, in the micro-interactions between actors as well as in interviews, reveals the ways in which the intertwining of the two worlds takes place. In the rugby of Sāmoa, there is a split between two types of practice, one in the villages and one in the formal sporting structure. IRB representatives focus on the latter, inherited from New Zealand during the colonial period: schools, clubs, unions, and so on. In the meantime, untitled men in the villages relax every evening playing touch rugby. IRB representatives are quite oblivious to the social dynamics of Samoan villages. Instead, they describe Samoan techniques 
as "flair" and their physical style of play as "being naturally strong" and "aggressive." These qualities are essentialized in the line of old clichés about Pacific masculinity.

This situation is instructive, as it makes visible the way that such qualifications are reactivated in a new context. It also shows how rugby is at the intersection of two social worlds. Whereas a pessimistic view would consider that one party gains what the other loses, here the two worlds exist simultaneously, with village rugby neither disappearing nor splitting from international policy. As fa'asāmoa is inscribed in the everyday touch rugby games, in the stadium where games are played, and in the embodiment of masculine players, rugby in Sāmoa gains its own unique Samoan identity.

\section{Notes}

I In a vein similar to common discourses on football (soccer) stereotypes, rugby "styles" can be viewed in "paradoxical, if not discursively incoherent" ways (see Crolley and others 2000, I26).

2 See Grainger 2009; Grainger and others 20I2; Hokowhitu 2003, 2004; Tengan and Markham 2009; Henderson 20II; and for Polynesian women in sport, Schaaf 2005 .

3 The name Manu Samoa was chosen for the national team by the Samoan Rugby Union. It is also a name of a chiefly title that refers to a famous Samoan warrior.

4 The Samoan archipelago was divided between Germany and the United States in I899 along the I7I west longitude, with the western part becoming German and the eastern part American. At the beginning of the First World War, Western Sāmoa was taken over by New Zealand. After each world war, the Society of Nations and the United Nations granted New Zealand a mandate and a trusteeship, respectively, for Western Sāmoa. Independent since 1962 and a member of the United Nations since 1975, Western Sāmoa is officially called "Sāmoa" since a I997 parliamentary vote (Davidson I967; Meleisea I987a, I987b).

5 Slightly more than 80 percent of the land in Sàmoa is held by customary tenure; of the remainder, the government holds I 5 percent and 4 percent is private property (Meleisea 1987b; Tcherkézoff 2003).

6 This claim - that Samoan touch rugby play differs, for example, from that of French youths playing in their towns-is a central point developed in my research through a detailed analysis of these body techniques (Clément 2009, 2010, forthcoming 20I4). 
7 See, for instance, the French Rugby Union's coach-training handbook titled Le Classeur d'entrainement, Ier cycle.

8 See, for example, the New Zealand Rugby Union's coach-training handbook titled Coaching for Secondary School Rugby, Handbook (Revised edition, 2007).

9 In addition to the spectators present at the games, many people report having listened on the radio to support their team if other responsibilities kept them away from the field. The translation is mine.

\section{References}

Belich, James

200I Paradise Reforged: A History of the New Zealanders from the I $880 \mathrm{~s}$ to the Year 2000. Auckland: Penguin Books.

Besnier, Niko

20II On the Edge of the Global: Modern Anxieties in a Pacific Island Nation. Stanford: Stanford University Press.

2012 The Athlete's Body and the Global Condition: Tongan Rugby Players in Japan. American Ethnologist 39:49I-5 IO.

Bouthier, Daniel

2007 Que sais-je? Le rugby. Paris: Presses Universitaires de France.

Clément, Julien

2009 Le rugby de Samoa: Les techniques du corps entre fa'aSāmoa et mondialisation du sport. $\mathrm{PhD}$ dissertation, Université de Provence.

20 Iо Le rugby de Samoa: Entre fa'aSāmoa et globalisation du sport. In Les cultures sportives au regard de la globalisation, edited by Laurent Sébastien Fournier and Gilles Raveneau. Special issue of Journal des Anthropologues I20/I2I: IOI-I20.

Crolley, Liz, David Hand, and Ralf Jeutter

2000 Playing the Identity Card: Stereotypes in European Football. Soccer and Society I (2): IO7-I 28.

Davidson, James

I967 Samoa mo Samoa: The Emergence of the Independent State of Western Samoa. Melbourne: Oxford University Press.

Deleplace, René

I979 Rugby de mouvement, rugby total. Paris: Editions Education Physique et Sports.

Dewey, Robert, Jr

2006 "The Real Reason is to Fight for the Country": The Historic Expression of Power and Identity in Fiji Rugby. In Dreadlocks Vaka Vuku: Special Issue: Proceedings of the Pacific Epistemologies Conference, 
edited by Mohit Prasad, 76-79. Suva: Pacific Writing Forum for the School of Language, Arts, and Media, University of the South Pacific.

2008 Pacific Islands Rugby: Navigating the Global Professional Area. In The Changing Face of Rugby: The Union Game and Professionalism since 1995, edited by Greg Ryan, 82-108. Newcastle: Cambridge Scholarship Press.

Eisenberg, Christiane, Pierre Lanfranchi, Tony Mason, and Alfred Wahl 2004 FIFA I904-2004: Le Siècle du football. Paris: Le Cherche-Midi; Lausanne: FIFA.

Galliot, Sébastien

20I0 O le ta tatau: Couleur, tatouage et technique du corps à Samoa. In Décors des corps, edited by Gilles Boëtsch, Dominique Chevé, and Hélène Claudot-Hawad, 265-273. Paris: CNRs Éditions.

Grainger, Andrew

2009 Rugby Island Style: Paradise, Pacific People, and the Racialisation of Athletic Performance. Junctures: The Journal for Thematic Dialogue I 2 (June): 45-63.

Grainger, Andrew, Mark Falcous, and Joshua Newman

$20 \mathrm{2} 2$ Postcolonial Anxieties and the Browning of New Zealand Rugby. The Contemporary Pacific 24:267-295.

Henderson, April

20 I I Fleeting Substantiality: The Samoan Giant in US Popular Discourse. The Contemporary Pacific 23:269-302.

Hokowhitu, Brendan

2003 "Physical Beings": Stereotypes, Sport and the "Physical Education" of New Zealand Māori. Culture, Sport, Society 6 (2/3): 192-218.

2004 Tackling Māori Masculinities: Genealogy of Savagery in Sport. The Contemporary Pacific 1 6:259-284.

Holt, Richard

I989 Sport and the British: A Modern History. Oxford: Clarendon Press. Hutchins, Brett, and Murray Phillips

1999 Globalization and the Rugby World Cup. In Making the Rugby World: Race, Gender, Commerce, edited by Timothy Chandler and John Nauright, I49-I64. London: Frank Cass.

Mauss, Marcel

I979 Body Techniques. In Sociology and Psychology: Essays by Marcel Mauss, translated by B Brewster, 95-I23. London: Routledge \& Kegan Paul.

I990 The Gift: The Form and Reason for Exchange in Archaic Societies. Translated by W D Halls. London: Routledge. 
Meleisea, Malama

I987a Lagaga: A Short History of Western Samoa. Suva: Institute of Pacific Studies, University of the South Pacific.

I987b The Making of Modern Samoa: Traditional Authority and Colonial Administration in the Modern History of Western Samoa. Suva: Institute of Pacific Studies, University of the South Pacific.

Milner, George

I966 Samoan Dictionary, Samoan-English, English-Samoan. Auckland: Pasifika Press.

Ochs, Elinor

I988 Culture and Language Development, Language Acquisition and Language Socialization in a Samoan Village. Cambridge: Cambridge University Press.

Ryan, Greg

I993 Forerunners of the All Blacks: The I888-89 New Zealand Native Football Team in Britain, Australia and New Zealand. Christchurch: Canterbury University Press.

2005a The Contest for Rugby Supremacy: Accounting for the I905 All Blacks. Christchurch: Canterbury University Press.

2005b Tackling Rugby Myths: Rugby and New Zealand Society, I8542004. Dunedin: University of Otago Press.

Schaaf, R Michelle [née Saisoa'a]

2005 Pacific Island Women, Body Image and Sport. Paper given at World Indigenous Peoples' Conference on Education, Hamilton, New Zealand, 27 Nov-I Dec. http://eprintstetumu.otago.ac.nz/9/oI/Schaaf _Pacific_Island_women.pdf [accessed 24 Feb 20I4]

Schimmel, Kimberley

2005 Sport and International Political Economy: An Introduction. In The Political Economy of Sport, edited by John Nauright and Kimberley Schimmel, I-I 5. New York: Palgrave Macmillan.

Tcherkézoff, Serge

2003 Faa-Samoa, une identité polynésienne (économie, politique, sexualité): L'Anthropologie comme dialogue culturel. Paris: L'Harmattan.

Tengan, Ty P Kāwika, and Jesse Makani Markham

2009 Performing Polynesian Masculinities in American Football: From "Rainbows to Warriors." The International Journal of the History of Sport 26 (I 6): 24 I 2-243 I.

Uperesa, Fa'anofo Lisaclaire

2010 Fabled Futures: Development, Gridiron Football, and Transnational Movements in American Samoa. PhD dissertation in anthropology, Columbia University. 


\section{Abstract}

Sāmoa, Fiji, and Tonga have emerged as strong contenders in international rugby competitions in the last three decades. Meanwhile, rugby has been going through a period of "development" since the creation of the Rugby World Cup in 1987 and the introduction of professionalism in 1995. Here, I present an ethnography of rugby in Sāmoa that focuses on embodiment. Participant observation of practices as well as interviews illuminate how international norms and values are diffused within the sport structure, while a global sporting practice is indigenized and appropriated in the everyday practices of young Samoan men. In Samoan rugby, the emergence of "flair" appears as a category of analysis that naturalizes an embodied characteristic of Samoan village life. By denaturalizing "flair" in Samoan rugby, this article contributes to a critique of this notion, in addition to showing the assemblage that creates rugby in the Islands.

KEYWORDS: sport, rugby, Sāmoa, embodiment, development, masculinity 